\title{
Management Approach : The Virtuous Corporation as a Moral Agent for Sustainable Development
}

\section{Heikkurinen, Pasi}

Springer

2017

Heikkurinen, P 2017 , Management Approach : The Virtuous Corporation as a Moral Agent for Sustainable Development . in A J G Sison, G R Beabout \& I Ferrero (eds), Handbook of Virtue Ethics in Business and Management. 1st edn, International Handbooks in Business Ethics , Springer , pp. 1395-1404 . https://doi.org/10.1007/978-94-007-6510-8_61

http://hdl.handle.net/10138/310476

https://doi.org/10.1007/978-94-007-6510-8_61

acceptedVersion

Downloaded from Helda, University of Helsinki institutional repository.

This is an electronic reprint of the original article.

This reprint may differ from the original in pagination and typographic detail.

Please cite the original version. 


\title{
Management Approach: The Virtuous Corporation as a Moral Agent for Sustainable Development
}

\author{
Pasi Heikkurinen \\ University of Leeds, UK
}

\begin{abstract}
This chapter examines the corporation as a moral agent for sustainable development. While sustainable development in business organizations can be argued from utilityand duty-based ethical theories, it is suggested that virtue-based ethics is needed to develop a moral agency for sustainable development, as it focuses on the organizational character. In addition, it is proposed that the biosphere (the global sum of all ecosystems) is accepted as the ultimate principal for all planetary agents to avoid an anthropocentric and only inward-looking position typical for ethical theories. Thus, a business organization can work as a nexus for virtue and develop a moral agency that contributes to the well-being of the biosphere and all of its members.
\end{abstract}

Keywords Virtue, Corporation, Organization, Business ethics, Agent, Agency, Principal, Structure, Biosphere, Ecosophy

\section{Introduction}

Humanity is on the edge (Brown 2011), as current development has pushed, and continues pushing us over the safe operating space on the planet. According to Rockström et al. (2009), the transgression of planetary boundaries may trigger nonlinear, abrupt environmental change with catastrophic consequences. The worst-case scenario is a sixth mass extinction and the subsequent collapse of human civilization (Barnosky et al. 2011). To avoid such a tragedy, we need development that does not endanger existence but sustains and embraces it.

In this quest for more desirable development, the UN's Brundtland Commission made famous the concept of sustainable development. The report has been rightly criticized (see e.g., Hueting 1990; Lele 1991). Besides ignoring the needs of the nonhuman world, it reinforces the false assumption that economic development is a necessity for solving environmental problems. In so doing, the report falls short of identifying the root causes of unsustainable development, namely, the expansion of human needs and economic activity (Heikkurinen and Bonnedahl 2013). Nevertheless, while there are clear inadequacies in the report, it importantly legitimized the so-called spatial and temporal dimensions in the sustainability debate. Spatial sustainability refers to meeting the needs of the present generations in different places (or spaces) so that overriding priority is given to the essential needs of the world's poorest people. This spatial 
sustainability can be extended to cover all beings, not merely humans, to avoid the critique toward anthropocentrism. (According to the Merriam-Webster online dictionary, anthropocentric refers to (1) "considering human beings as the most significant entity of the universe" and/or (2) "interpreting or regarding the world in terms of human values and experiences.") Temporal sustainability refers to sustainable development in time. What this means is that if we are to ensure that future generations can meet their own needs, we have to start conserving natural resources and fostering the vitality of our planet's ecological processes. Since human labor, technology, and economics are no substitute for these resources and processes (Daly 1996), temporal sustainability goes well together with non-anthropocentric spatial sustainability. In practice, if we are to achieve development that can be sustained, we humans must adapt the nature of our activities to the carrying capacity of the planet and start caring for beings in need (in both time and space). Moreover, given our dependency on highly complex ecological processes that lie beyond current scientific understanding, the caring cannot be limited to the humans but must also include the animal, vegetable, and mineral kingdoms. Thus, any development ought to proceed with precaution so that we do not destabilize the delicate balance of the biosphere, the global sum of all ecosystems.

This rationale has profound implications for every human actor, as it leads us to conclude that the current state of affairs is unacceptably unsustainable, and we must therefore radically change. The present chapter argues that sustaining and embracing the diversity of all life forms should not be seen only through its utility for mankind (utilitybased ethics) but also as a moral duty (duty-based ethics) and, most importantly, an activity that a virtuous character does (virtue-based ethics). Becoming a virtuous moral agent for sustainable development is not merely a possibility for business practitioners but also an ethical necessity in the midst of ecological and humanitarian turmoil.

\section{Organization as a Moral Character}

In recent decades, we have witnessed an increase in the presence and power of corporate actors (Coghlan and MacKenzie 2011). This restructuring of societal life has come to mean that business managers have put themselves into a position where they are acting as significant agents for development, whether this will be sustainable or unsustainable. Attempting to sustain and embrace all forms of life in time and space is not a modest responsibility and should not therefore be left to the vagaries of the market and corporate actors (Heikkurinen 2013). However, given the current powerful position of business organizations in relation to our futures, it is very meaningful to examine the moral character of the corporation in detail.

While some authors deny the moral character of the corporation, others perceive the business organization as a moral character (French 1979; Collier 1995) and that "it is both meaningful and efficacious to ascribe the competency for conscious and intentional behavior to organizations" (Pruzan 2001, p. 271). After all, business organizations do consist of humans who have morality as an inherent characteristic. So, as well as having values, actions, and strategies, corporations can also have moral responsibilities

(Goodpaster and Matthews 2003). This implies that an organization, as a collectivity, 
can possess competencies normally attributed to individuals, i.e., to reflect, evaluate, learn, and make considered choices (Pruzan 2001). Pruzan (2001, p. 277) explains further:

\footnotetext{
It is a common experience than when individuals, each with their own values, preferences and expectations, meet to decide on matters of importance to an organization they belong to and for which they feel a sense of responsibility, a new, implicit - and shared - value can develop amongst the participants. This shared value which emerges in the group is to serve the organization - to reinforce both its identity and the sense of responsibility they have with respect to the organization as a whole - and to arrive at decisions which are acceptable for all the participants.
}

Thus, according to Moore (1999, p. 341), "the issue becomes whether we can speak only of the moral character of individuals within the context of organizations or whether, in addition, we can speak of the moral character of the organisation as a whole." In other words, the idea of moral character denotes an organization's ability to make moral choices. Which choices are then made and how the decisions are reached arguably depend on the organizational character at issue. And what is important here is that by accepting the idea of organizational moral character, we are able to discuss the moral agency of the corporation.

\section{Moral Agency of the Corporation}

Research on corporate moral agency connects to two important streams of research, namely, structure-agency and principal-agent debates. The first is concerned on a broad debate on structure versus agency that attempts to explain why organizations act in a specific manner. At one extreme, a group of scholars claim that structure (for instance, societal institutions) determines organizational behavior, while the other extreme posits that organizations are independent and free to act in any manner they wish. The middle ground here would be to say that while agents have a degree of autonomy, they are also constrained by the structures in which they are embedded. At a first glance, this notion might appear slightly trivial and then seem somewhat paradoxical, but lastly it somehow ends up feeling intuitively pleasing. The reason for this can be found, for instance, in the following thought: if agents are not treated as one homogeneous group, the paradox starts to evaporate. So, it is suggested that an allencompassing view on how agents act in relation to structures is and will not be available to us. There is no single type of agency that shapes organizational behavior or is being shaped by structures. Thus, we need to carefully study agents in relation to different sorts of structures, as agents differ in how they act in relation to them. This means that the structure-agency problem is not an either/or question but more nuanced. Agency and structure are hence considered as complementary rather than opposing forces (Bourdieu 1977). Structure influences human behavior, while humans are also capable of changing the social structures in which they are embedded (Giddens 1984). Another stream of research has approached the question of moral agency from another point of view. In explaining organizational behavior, agents have been examined in relation to their principals. This principal-agent problem explores, e.g., whose interests the agents are serving. Typically, in organization and management studies, the so-called agency theory has been applied between corporate managers (agents) and corporate shareholders (principals) (for a review see Eisenhardt 1989). The realization that 
managers (agents) do not always act in line with the desires of shareholders (principals) was significant for the field of management science. It meant that academic scholars needed to find better ways to enable the owning class (principals) to keep track of and control the agents (managers and employees) for their purposes. Nevertheless, what is important here is the discovery that agency is not limited to considering shareholders as the only principals. Modern actors are, on the contrary, authorized agents for various interests (Meyer and Jepperson 2000). And if we consider organization as the agent, then we can regard its principals to basically be anything whose interests the agent serves. This leads us to assume that agents can in fact have many principals. These can be individuals and/or groups of beings, even imaginary friends. Which objects are then chosen as the principals is a question of organizational politics, but importantly also influenced by the worldview of managers.

\section{Biosphere as the Principal and Structure for the Agent}

In sustainable development, overriding priority is given to the vital needs of the world's most disadvantaged beings, as well as the needs of future beings. Thus, for an organizational agent aiming at sustainable development, the principals are the current and future beings combined. It is not of great significance what the entity of metaphysical life should be referred to as (be it the universe, prana, god, web of life, or another similar term), but what is important is to acknowledge, respect, and protect the entity that enables physical, material life on this planet. While the significance of the sun and other objects in outer space should be acknowledged, the emphasis in the search for sustainable development is still meaningful to keep on the current and future inhabitants of the Earth. The principal of highest rank is then the ecological entity on the planet, the biosphere.

The international scientific community has never been as unanimous that climate change is largely anthropogenic. This means that organized human actions have had an effect on the balance of the biosphere. In the light of scientific knowledge, we also know that our actions have led to the collapse of ecosystems, which may lead to the next mass extinction, in which over $75 \%$ of the species may be lost (Barnosky et al. 2011). In such a worst-case scenario, it is no longer meaningful to discuss the needs of the current and future beings. Assuming that we are to survive the extinction wave, the primitive search for food and shelter will become an intrinsic part of everyday life. In any case, it is fair to suggest that the biosphere is the ultimate structure and principal for all agents on the planet Earth. Ecosystems (that together comprise the biosphere) form the structure in which all humans and organizations are embedded. This ecosystemic structure holds material life and existence together on our planet. Thus, if we are to sustain existence and foster life within the biosphere, it is reasonable to conclude that the biosphere is also the principal. For organization and management studies, the biosphere as the ultimate principal means that radically new ways of organizing economic activities must be found. This needed change, however, necessitates the development of a type of moral character. Normative ethical theories may help us in this task. 


\section{Normative Ethical Theories and Sustainable Development}

Normative ethical theories analyze and suggest to us what is a morally sound way of acting in a specific situation. These theories study the norms in ethics and attempt to answer the question of what is right or wrong. There are three main normative ethical theories that express on a rather generic level why certain actions are more desirable than others. These theories are utility-based, duty-based, and virtue-based ethics. For sustainable development in business organizations, each of them offers a different kind of rationale for engaging in sustainability.

Utility-based ethics: sustainability as a utility. Utility-based ethics considers that the consequences of an act are morally significant. The most famous utilitarian ethicists are Jeremy Bentham, John Stuart Mill, and Henry Sidgwick. According to these scholars, an act is morally sound if it produces the maximum amount of overall utility for the general good. Utility-based analysis weighs between the utility and harm produced by an act and then advises choosing the least harm and maximum utility. In Mill's book Utilitarianism (1861), utility becomes translated into happiness, pleasure, and an absence of pain. In economics and management science, the tool for conducting such evaluations is cost-benefit analysis. This analysis typically assigns a monetary value to all things, be they humans or nonhuman objects. The strength of utility-based ethics is that if offers a generic principle for all ethical problems, but it also has many major weaknesses. On the ontological level, the problem is that utility-based ethics reduces thinking and actions to consider all objects as means or instruments for something else. However, we humans often also give intrinsic value to others and ourselves. An epistemological problem again is that we never know the outcomes of our actions in advance. So, how are we supposed to conduct an analysis without such knowledge? This leads us to a methodological problem of utility-based ethics. It assumes that we are able (and willing) to assign a value to all beings and objects and be able to estimate the utility for the general good. However, because we are often unable to do this in practice, the ethics can easily lead to egoistic ethics, in which a person or an organization considers the overall utility as a synonym for personal utility (Ketola 2008a).

Furthermore, thinking only about the utility of objects can lead to intuitively rather repulsive mental models, such as killing 50 now to save 100 later. But be that as it may, in the context of sustainable development, utility-based ethics could suggest that an organization should act sustainably, because sustainable action has higher utility for humanity than unsustainable action. This position could be described as "sustainability as a utility."

Duty-based ethics: sustainability as a duty. Since in utility-based ethics the motives of the actor do not matter, we should complement our inquiry for sustainable development with duty-based ethics. The founding father of this school of thought was Immanuel Kant. Contrary to utility-based ethics, in which moral goodness is dependent on the utility an act can deliver, duty-based ethics puts the intention and motives of an act on center stage. The motives are important, because if an organization merely attempts to match its good deeds with the available utility, it ends up delivering as little goodness as possible. In other words, the utilitarian rationale leads us to a situation where only the minimum amount of a moral act is practiced. And assuming that such a calculation was possible, when the utility is no longer available, good deeds would no longer be done. 
To put this problem in the context of sustainable development, preserving and fostering the existence of life would stop when utility for humans was no longer delivered.

Hence, to avoid these problems of the utilitarian mind, duty-based ethics offers a tool for thought, namely, the categorical imperative. In Groundwork of the Metaphysics of Morals, Kant (1785) put forward the basic premise of the imperative, which is to "Act only on that maxim through which you can at the same time will that it should become a universal law" (Kant 1785/2009, p. 30). The categorical imperative also proposes that a person should act in a manner in which one treats humanity not only as means but also as ends in itself. In other words, the main idea is to form principles for action that create a duty for the agent and hold in every situation. An individual can arrive at such a principle by thinking rationally whether the principle could be a universal law. Morality is thus not a mechanical calculus exercise on the pros and cons for different people in different situations, but the duty of an agent that is based on predetermined obligations and rules. While this view on ethics provides an important supplement to our moral inquiry for sustainability, it falls short on some aspects. For instance, as duty ethics emphasizes rationality, emotions are left outside the moral decision-making. Yet, they are a key part of being human. Also, one could ask: is not the development of a moral character more important than the rules and guidelines that obligate the agent? In any case, in the context of sustainable development, duty-based ethics importantly suggests that an organization should always act sustainably because it is its duty, as the principle of sustainable actions meets the requirement of the categorical imperative. This position could be described as "sustainability as a duty."

Virtue-based ethics: sustainability as a virtue. Duty-based ethics, which emphasizes motives (ethical input), is complementary to utility-based ethics, which emphasizes consequences (ethical output). In between lies virtue-based ethics, which places emphasis on the development of an agent's character (ethical process). According to Ketola (2008a, p. 422), the ethics of virtue originate from the works of "Socrates, Plato and particularly Aristotle" (384-322 BC). This approach to morality gives priority to neither good motives nor good consequences but considers both of them to be connected to a virtuous character. The analysis is focused on determining what kind of character an organization has if we consider its whole life cycle. Thus, central to the virtue theory are not the guidelines or utility of a single act but a good life overall. In Nicomachean Ethics, Aristotle (348 BC/1999) "describes a virtue as an attitude that makes people good and helps them do their work well" (Ketola 2008a, p. 422). The same idea could be applied to collectives such as organizations, such that virtue makes organizations morally good and helps them in their practices. Furthermore, for Aristotle, "virtue is a middle road between two evils" (Ketola 2008b, p. 76), in which rationality and emotion work together in harmony. The main challenge of virtue-based ethics is its abstractedness and difficulty. It is rather challenging for many organizations to develop a virtuous character if they have nurtured the psychopathic side of their persona (see Ketola 2008b). However, it is worth a try, as such a character is never unachievable. And in the context of sustainable development, the attempt can even be considered as a necessity. In our quest for a livable planet, virtue-based ethics suggests that an organization should act sustainably because sustainability is a virtue. The two evils between which sustainability could be positioned are extreme extravagancy and affluence, which is achieved through continuous socioeconomic activity that leads to the maximal use of resources and stress on ecosystems, and extreme scarcity and poverty, 
which is achieved through refraining from any socioeconomic activity and the liquidation of one's own life in order to achieve the minimal use of resources and stress on ecosystems. A close virtue to sustainability could also be sufficiency (Table 1).

Table 1

Normative ethical theories for sustainable development in corporations

\begin{tabular}{|l|l|l|}
\hline Utility-based ethics & Duty-based ethics & Virtue-based ethics \\
\hline $\begin{array}{l}\text { It is beneficial that } \\
\text { corporations act in line } \\
\text { with sustainable } \\
\text { development }\end{array}$ & $\begin{array}{l}\text { It is a corporate duty to } \\
\text { act in line with } \\
\text { sustainable } \\
\text { development }\end{array}$ & $\begin{array}{l}\text { A virtuous corporation } \\
\text { acts in line with } \\
\text { sustainable } \\
\text { development }\end{array}$ \\
\hline $\begin{array}{l}\text { "Sustainability as a } \\
\text { utility" }\end{array}$ & $\begin{array}{l}\text { "Sustainability as a } \\
\text { duty" }\end{array}$ & $\begin{array}{l}\text { "Sustainability as a } \\
\text { virtue" }\end{array}$ \\
\hline
\end{tabular}

There is an ontological, collective deficiency in all three normative ethical theories. They are all anthropocentric. The theories consider humans as the most significant object in the universe and interpret the world as if all humans would agree to perceived life only through human experience and value. In the quest for sustainable development, where we seek development that does not endanger existence but sustains and embraces it in all its forms, we need to extend utility-, duty-, and virtue-based ethics to also cover nonhuman existence. This is not, however, a problem, as many biocentric authors, such as the philosopher Arne Naess, have worked with this issue for decades (for organization and management studies, see Ketola 2010; Heikkurinen et al. 2016). To avoid the trap of anthropocentrism, Naess, in his book Ecology, community and lifestyle (1989), provides an outline of an ecosophy that gives inherent worth to all living beings, regardless of their instrumental utility for human needs. However, such broadened egalitarianism only works only in principle. This is because "any realistic praxis necessitates some killing, exploitation, and suppression" (Naess 1989/2001, p. 28). Moreover, Naess (ibid) explains biospherical egalitarianism as follows:

\footnotetext{
The ecological field worker acquires a deep-seated respect, even veneration, for ways and forms of life. He reaches an understanding from within, a kind of understanding that others reserve for fellow men and for a narrow selection of ways and forms of life. To the ecological field worker, the equal right to live and blossom is an intuitively clear and obvious value axiom. Its restriction to human is an anthropocentrism with detrimental effects upon the life quality of humans themselves. This quality depends in part upon the deep pleasure and satisfaction we receive from close partnership with other forms of life. The attempt to ignore our dependence and to establish a master-slave role has contributed to the alienation of man from himself.
}

In other words, and perhaps somewhat paradoxically, we humans may become forced to leave still largely prevailing anthropocentric premises behind in order to save our species while not destroying others. In practice, this would firstly mean recognizing the 
agent's place within the complex biosphere. This has a fundamental message for structure-agency problematization, as it forces us to admit the hierarchical relationship between the biosphere (structure) and organization (agent). An agent (a human organization) cannot exist without the structure (the biosphere), but the structure surely can exist without the agent. If we assume the biosphere not only as a structure but also as the ultimate principal, then we could say that the principal (the biosphere) might even be better off without the agent (a human organization), as it does not act in line with the interests of the principal. To respect the structures and the principal, we need an agentfocused approach to the virtuous corporation.

\section{Conclusion}

While utility and motive-based ethics are surely important in the pursuit of sustainable development, virtue-based ethics offers solid groundings for a moral agency to develop because of its focus on the character itself (Ketola 2008a). Slote (1997, p. 240) distinguishes virtue-based ethics, which focuses more on virtuous characters and their traits, from more agent-focused theories that "treat the moral or ethical status of actions as entirely derivate from independent and fundamental ethical/aretaic facts (or claims) about the motives, dispositions, or inner life of the individuals who perform them." Such an agent-focused approach to virtue is well suited to the challenge of sustainable development, as (a) sustainability is largely defined by the external environment of the agent and (b) the biosphere is the ultimate principal of all agents on the planet. An approach to virtue-based ethics that places special emphasis on the development of nonanthropocentric moral character (e.g., Ketola 2010) makes it an excellent platform to analyze organized economic activity in relation to the natural environment. Business organizations can now "create environments that can either favor or hinder the personal development of workers" (Fontrodona et al. 2013, p. 563), as well the moral development of the organization as a collective of humans (Ketola 2010) and nonhuman beings.

Even though sustainable development can be argued from utility- and duty-based ethical theories, it is suggested that virtue-based ethics with an agent-focused twist is well suited to the challenge of sustainable development. The idea of virtue offers an important lens to examine the moral development of organizational character, while the notion of agency directs the inquiry to include the biosphere as the ultimate principal.

\section{References}

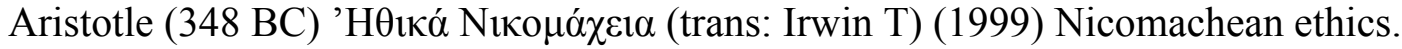
Hackett Publishing, Indianapolis

Barnosky AD, Matzke N, Tomiya S, Wogan GOU, Swartz B, Quental TB, Marshall C, McGuire JL, Lindsey EL, Maguire KC, Mersey B, Ferrer EA (2011) Has the Earth's sixth mass extinction already arrived? Nature 471:51-57 
Bourdieu P (1977) Outline of a theory of practice. Cambridge University Press, Cambridge

Brown LR (2011) World on the edge. How to prevent environmental and economic collapse. WW Norton, New York

Coghlan A, MacKenzie D (2011) The hard core of power. New Sci 212:8-9

Collier J (1995) The virtuous organization. Bus Ethics 4:143-149

Daly HE (1996) Beyond growth. Beacon, Boston

Eisenhardt KM (1989) Agency theory: an assessment and review. Acad Manage Rev 14:57-74

Fontrodona J, Sison AJG, de Bruin B (2013) Editorial introduction: putting virtues into practice. A challenge for business and organizations. J Bus Ethics 113:563-565

French PA (1979) The corporate as a moral person. Am Philos Q 16:207-215

Giddens A (1984) The constitution of society: outline of the theory of structuration. Polity Press, Cambridge

Goodpaster KE, Matthews JB (2003) Can a corporation have a conscience. In: Harvard business review on corporate social responsibility. Harvard Business School Publishing, Boston

Heikkurinen P (2013) Reframing strategic corporate responsibility: from economic instrumentalism and stakeholder thinking to awareness and sustainable development. Doctoral dissertation, Aalto University, Helsinki

Heikkurinen P, Bonnedahl KJ (2013) Corporate responsibility for sustainable development: a review and conceptual comparison of market- and stakeholder-oriented strategies. J Clean Prod 43:191-198

Heikkurinen P, Rinkinen J, Järvensivu T, Wilén K, Ruuska T (2015) Organising in the Anthropocene: an ontological outline for ecocentric theorising. J Clean Prod 113:705714

Hueting R (1990) The Brundtland report: a matter of conflicting goals. Ecol Econ 2:109-117

Kant I (1785) Grundlegung zur Metaphysik der Sitten (trans: English by Paton HJ) (2009) Groundwork of the metaphysics of morals. HarperCollins Publishers, New York

Ketola T (2008a) A holistic corporate responsibility model: integrating values, discourses and actions. J Bus Ethics 80:419-435 
Ketola T (2008b) From psychopaths to responsible corporation: waking up the inner sleeping beauty of companies. Nova Science Publications, New York

Ketola T (2010) Five leaps to corporate sustainability through a corporate responsibility portfolio matrix. Corp Soc Responsib Environ Manag 17:320-336

Lele SM (1991) Sustainable development: a critical review. World Dev 19:607-621

Meyer JW, Jepperson RL (2000) The "actors" of modern society: the cultural construction of social agency. Sociol Theory 18:100-120

Mill JS (1861) Utilitarianism (trans: Finnish by Saastamoinen K, Sajama S, Järvenpää M) (2000) Utilitarismi. Gaudeamus, Helsinki

Moore G (1999) Corporate moral agency: review and implications. J Bus Ethics 21:329-343

Naess A (1989) Økologi, samfunn og livsstil utkast til en økosofi (trans: English by Rothenburg D) (2001) Ecology, community and lifestyle: outline of an ecosophy. Cambridge University Press, Cambridge

Pruzan P (2001) The question of organizational consciousness: can organizations have values, virtues and visions? J Bus Ethics 29:271-284

Rockström J, Steffen W, Noone K, Persson Å, Chapin FS, Lambin EF, Lenton TM, Scheffer M, Folke C, Schellnhuber HJ, Nykvist B, de Wit CA, Hughes T, van der Leeuw S, Rodhe H, Sörlin S, Snyder PK, Costanza R, Svedin U, Falkenmark M, Karlberg L, Corell RW, Fabry VJ, Hansen J, Walker B, Liverman D, Richardson K, Crutzen P, Foley JA (2009) A safe operating space for humanity. Nature 461:472-475

Slote M (1997) Agent-based virtue ethics. In: Crisp R, Slote M (eds) Virtue ethics. Oxford University Press, Oxford 